\title{
Household Expenses after An Increase in Basic Tariff of Electricity in Pekanbaru
}

\author{
Prama Widayat ${ }^{1}$ and Ryan Pahlawan ${ }^{2}$ \\ ${ }^{1}$ Lancang Kuning University, Pekanbaru, Indonesia \\ $\varangle$ (e-mail) pramawidayat@unilak.ac.id \\ ${ }^{2}$ Lancang Kuning University, Pekanbaru, Indonesia \\ $\triangle$ (e-mail) ryanpahlawan@unilak.ac.id
}

\begin{abstract}
Electricity is a basic human need besides other staples, either for those of the small or large income. Those who are less able are given subsidies from the government, but in 2017 the Indonesian government unilaterally increased the electric base rate (TDL) which certainly imposes on electricity bills. Therefore, the purpose of this study is to see how the burden of expenditure borne by the household after the increase. It was found that empirically the average in the expenditure of the communities after the increase was around IDR100,000 to IDR150,000, meanwhile, the average income level is IDR0 to IDR2.3 millions. The tariff increase is not accompanied by revenue increase; thus, societies have to sacrifice other expenses for the sake of covering electricity cost.
\end{abstract}

Keywords: household expenses, expenditure, electricity tariff

\section{Introduction}

The purpose of this study is to see how the burden is borne by every household after the increase in electricity tariff, the burden of household expenditure will certainly increase after the increase and not offset by the increase in income. This is greatly felt by households that use 450 watts of power up to 900 watts. If household expenditure is used too much for consumption then when they use it for communication purpose, also for internet data packets, it can reach IDR100,000 to IDR200,000 per month

The use of electricity ranges from 450 watts, 900 watts, 1200 watts and above 1200 watts. The need is dependent on the family income among the societies. In 2017, the Indonesian government has raised the basic tariff of electricity without issuing notice to its society, whereas, it concerns with public life in the city.

The community was so surprised when the electric bill for pre-paid or post-paid, for city area also underwent a rise in price all over Indonesia. The government was supposed to socialize concerning the issues of the rise because people have been experiencing economic difficulties in recent years. As a result, the community raised a protest.

In March 2017, the government already raised the basic tariff. This could be seen in electric capacity of 900 watts token power supply with the value of purchase of IDR 50,000 getting $63 \mathrm{kwh}$ (IDR793 per kwh) while before it was $75 \mathrm{kwh}$ (IDR666 per kwh). Then in June 2017, without any earlier notice, the price raised again that IDR50,000 purchase tokens (IDR1,136 per kwh) was given only $44 \mathrm{kwh}$. Through the year of 2017, the government has already increased the tariff up to more than $100 \%$. The government through the Minister of Mineral Resources stated that there will be no more price raise until December 2017. In the absence of electricity tariff increase or by not changing it until December 2017, then tariffs for low voltage customers (TR) is IDR1,467.28 per kilo watt hour $(\mathrm{kWh})$, medium voltage electricity rates (TM) is IDR1,114 ultra-compact per $\mathrm{kWh}$, electricity rates voltage high (TT) is IDR996.74 per kWh, and electricity rates in the Special Service is of IDR1,644.52 per kWh (www.liputan6.com).

Electricity tariff rates 13, in which the customers are currently no longer subsidized are: R1 households with low voltage power supply, $900 \mathrm{VA}$, R1-homes with low voltage power supply, 1300 VA, R1-home with low voltage power, 2200 VA, R1- secondary Home with low voltage power supply 
ranging from 3500 to $5500 \mathrm{VA}, \mathrm{R} 3-$ primary homes with low voltage power $6600 \mathrm{VA}$ upwards, B2intermediate Business with low voltage power supply, 6600 VA up to $200 \mathrm{KVA}$, B3-big business with low voltage power above $200 \mathrm{kVA}$, P1-government Office with low-power, $6600 \mathrm{VA}$ to $200 \mathrm{kVA}$, I3 Industrial use- secondary medium voltage power above $200 \mathrm{kVA}$, I4 industrial high voltage power 30 MVA and above, P2- government Office with medium voltage power above $200 \mathrm{kVA}$, P3-public street light with low voltage and L-special services.

Managing Director of the State Electricity Company (PLN), Sofyan Basir, commented that the issue of basic electricity increase rate was deliberately presented to put it into government's concern. Regarding the rise in electricity price perceived by some consumers, it is because consumers classified as the middle economy have been receiving electricity subsidies that should have been given to people with low income.

Government statement is inconsistent, in its preliminary statements it was said that there would be no increase except only partial increase of consumers classified as medium economy. Thus, does the government have a category to define middle-class society, or just let it be more easily seen from the minimum wage? For the city of Pekanbaru, the minimum wage is IDR2.352.570 (pekanbaru.tribunnews.com). Can, then, those who earn UMK (minimum wage) be categorized as economically capable?

An increase in TDL above 100\% during 2017 is considered very burdensome in middle-class society up to lower-class society. It is, of course, household expenses will increase in line with the increase in electricity bills paid per month including those who use electricity token (the electricity prepaid voucher). While the salary did not increase, inflation was predicted to rise by $0.30 \%$ (business tempo), and this impact also takes place in Pekanbaru. The same problem occurs not only in big cities in Indonesia, but also in Pekanbaru, in terms of living cost. Before the increase in basic tariff of electricity price, household expenses are hard enough to meet especially the primary needs, education and other expenses.

\section{Methods}

The population in this research is households in the city of Pekanbaru. The respondents in this research were selected using random sampling method resulting with 567 respondents. This research used descriptive method in order to look at household expenses after the increase of basic electricity rate (TDL). The data collection was conducted by carrying out a detailed survey questionnaire and interviews with some employees.

\section{Results and Discussion}

\section{Results}

Table 1 Respondents income

\begin{tabular}{ccc}
\hline $\begin{array}{c}\text { Number of } \\
\text { Income }\end{array}$ & Respondent & Percentage \\
\hline $\begin{array}{c}\text { IDR0 - } \\
\text { IDR2.300.000 }\end{array}$ & 315 & $57 \%$ \\
\hline $\begin{array}{c}\text { IDR2.300.001 - } \\
\text { IDR5.000.000 }\end{array}$ & 189 & $34 \%$ \\
\hline $\begin{array}{c}\text { IDR5.000.0001 - } \\
\text { IDR8.000.000 }\end{array}$ & 50 & $7 \%$ \\
\hline $\begin{array}{c}\text { Above } \\
\text { IDR8.000.001 }\end{array}$ & 13 & $2 \%$ \\
\hline TOTAL & 567 & $100 \%$ \\
\hline
\end{tabular}


The data were taken from 567 respondents and around 1,011,467 population. From Table 1, it can be seen that the average community income is at IDR 0 to IDR2.3 million and it is the city's minimum wage (UMK). From this data, it is seen that the society is dependent on minimum wage, and only a small proportion of societies who have income above IDR 8 million which means $2 \%$ only.

Table 2 Distribution of capacity

\begin{tabular}{lcc}
\hline Capacity & Respondent & Percentage \\
\hline 450 VA & 9 & $1,5 \%$ \\
\hline $900 \mathrm{VA}$ & 387 & $68 \%$ \\
\hline $1200 \mathrm{VA}$ & 162 & $29 \%$ \\
\hline Above 1200 VA & 9 & $1,5 \%$ \\
\hline TOTAL & 567 & $100 \%$ \\
\hline
\end{tabular}

Table 2 shows that most household electricity consumption of Pekanbaru households is 900 VA capacity as much as $68 \%$, followed by 1200 VA capacity as much as $29 \%$. Only $2 \%$ are using electricity above 1200 VA. The electricity use is dominated by housing Type 36 and simple Community House outside housing, but for those who live in houses using electricity on average above 1200 VA needs to trade. While only three houses a scale of priorities the need for television, rice cooker, a fan or Air Conditioning, engine water pump and lights.

Table 3 Monthly costs for capacity of $450 \mathrm{VA}$

\begin{tabular}{cccc}
\hline Income Rates & $\begin{array}{c}\text { Number of } \\
\text { Respondents }\end{array}$ & $\begin{array}{c}\text { Average } \\
\text { before the } \\
\text { increase (IDR) }\end{array}$ & $\begin{array}{c}\text { Average after the } \\
\text { increase (IDR) }\end{array}$ \\
\hline $\begin{array}{c}\text { IDR0 - } \\
\text { IDR2.300.000 }\end{array}$ & 10 & 180.000 & 230.000 \\
\hline IDR 2.300.001 & - & - & - \\
IDR5.000.000 & - & - & - \\
\hline $\begin{array}{c}\text { IDR5.000.0001 } \\
-\end{array}$ & - & - & - \\
IDR8.000.000 & & & 230.000 \\
\hline $\begin{array}{l}\text { Above } \\
\text { IDR8.000.001 }\end{array}$ & - & 180.000 & \\
\hline TOTAL & 10 & & \\
\hline
\end{tabular}

Based on table 3 that the expenses for electricity $450 \mathrm{VA}$ average before the price rise of basic tariff is IDR 180,000, and after the ascension it increase to IDR 230,000. So, the increase in expenses for electricity bill is IDR 50,000.

Table 4 Monthly cost for capacity of $900 \mathrm{VA}$

\begin{tabular}{lccc}
\hline \multicolumn{1}{c}{ Income Rates } & $\begin{array}{c}\text { Number of } \\
\text { Respondents }\end{array}$ & $\begin{array}{c}\text { Average } \\
\text { before the } \\
\text { Increase (IDR) }\end{array}$ & $\begin{array}{c}\text { Average after } \\
\text { the increase } \\
\text { (IDR) }\end{array}$ \\
\hline $\begin{array}{l}\text { IDR0 - } \\
\text { IDR2.300.000 }\end{array}$ & 305 & 155.000 & 300.000 \\
\hline $\begin{array}{l}\text { IDR2.300.001 - } \\
\text { IDR 5.000.000 }\end{array}$ & 150 & 200.000 & 350.000 \\
\hline $\begin{array}{l}\text { IDR5.000.0001 - } \\
\text { IDR 8.000.000 }\end{array}$ & 42 & 250.000 & 400.000 \\
\hline $\begin{array}{l}\text { Above IDR } \\
8.000 .001\end{array}$ & 8 & 300.000 & 500.000 \\
\hline \multicolumn{1}{c}{ TOTAL } & 505 & 227.000 & 387.000 \\
\hline
\end{tabular}


Table 5 Monthly cost for capacity of $1200 \mathrm{VA}$

\begin{tabular}{lccc}
\hline \multicolumn{1}{c}{ Income Rates } & $\begin{array}{c}\text { Number of } \\
\text { Respondents }\end{array}$ & $\begin{array}{c}\text { Average before the } \\
\text { Increase (IDR) }\end{array}$ & $\begin{array}{c}\text { Average after the } \\
\text { increase (IDR) }\end{array}$ \\
\hline $\begin{array}{l}\text { IDR0 - } \\
\text { IDR2.300.000 }\end{array}$ & - & - & - \\
\hline $\begin{array}{l}\text { IDR 2.300.001 - } \\
\text { IDR5.000.000 }\end{array}$ & 37 & 250.000 & 450.000 \\
\hline $\begin{array}{l}\text { IDR5.000.0001 - } \\
\text { IDR8.000.000 }\end{array}$ & 7 & 750.000 & 800.000 \\
\hline $\begin{array}{l}\text { Above } \\
\text { IDR8.000.001 }\end{array}$ & 2 & 800.000 & 1.000 .000 \\
\hline \multicolumn{1}{c}{ TOTAL } & 46 & 600.000 & 750.000 \\
\hline
\end{tabular}

Table 5 displays electricity use with the capacity of 1200 VA household spending before and after the rise, IDR600,000 to IDR750,000, so the average increase of household expenses reaches to IDR150,000 per month.

Table 6 Monthly cost for capacity above $1200 \mathrm{VA}$

\begin{tabular}{lccc}
\hline Income Rates & $\begin{array}{c}\text { Number of } \\
\text { Respondents }\end{array}$ & $\begin{array}{c}\text { Average before } \\
\text { the Increase (IDR) }\end{array}$ & $\begin{array}{c}\text { Average after the } \\
\text { increase (IDR) }\end{array}$ \\
\hline $\begin{array}{l}\text { IDR0 - } \\
\text { IDR2.300.000 }\end{array}$ & - & - & - \\
\hline $\begin{array}{l}\text { IDR2.300.001- } \\
\text { IDR5.000.000 }\end{array}$ & 2 & 200.000 & 400.000 \\
\hline $\begin{array}{l}\text { IDR5.000.0001 - } \\
\text { IDR8.000.000 }\end{array}$ & 1 & 650.000 & 700.000 \\
\hline $\begin{array}{l}\text { Above } \\
\text { IDR8.000.001 }\end{array}$ & 3 & 750.000 & 820.000 \\
\hline TOTAL & 6 & 800.000 & 960.000 \\
\hline
\end{tabular}

Table 6 shows household expenses for electricity with the capacity above 1200 VA before and after, IDR 800,000 to IDR 960,000, so the average household spending increases for the electricity bill is IDR 160,000 per month.

\section{Discussions}

Based on the above data it can be interpreted that the income levels of society in Pekanbaru is still dominated by those who earn minimum wage as of $57 \%$ meaning that they still rely on private-sector employees working on the lower level, labors and other types of labors. Those who work as employees in private sectors are considered to have incomes above minimum wage. This class belongs to the level of supervisor or middle management. If minimum income is IDR 2,300,000, it will be so hard to manage the expenditure that it will surely be heavier with an increase in basic tariff reaching 100\% (one hundred percent) for 900 VA power throughout 2017. Research result Purbaningrum (2014) mentioned that the consumption of electricity within the power capacity of 450 VA was of 73, 117KWh/month, $900 \mathrm{VA}$-power of $124.409 \mathrm{KWh} / \mathrm{month}$ then 1,300 power of 257.068 $\mathrm{KWh} /$ month. That household electrical consumption is dominant at $900 \mathrm{VA}$ and $1300 \mathrm{VA}$.

Households who earn IDR2.3 million average has 1 (one) and 2 (two) children while the wife just profession as a housewife. If we do surgery expenditures for households with 2 (two) children and establishes signed with electricity $900 \mathrm{VA}$.

With the requirements set forth in table 7, how could a family survive with minimum income, IDR2.3 million whereas the household expenses can reach up to IDR2,290,000. This sometimes forces the wife to make money by doing extra job, like selling hand-make cakes, for example. But this is only 
a small part. If the family can't afford, they have to reduce their monthly needs excluding in an emergency situation that also requires cost.

Table 7 Details of Household Expenditure before the Increase in Basic Tariff of Electricity Price

\begin{tabular}{lcc}
\hline \multicolumn{1}{c}{ Item } & descriptions & Amount (IDR) \\
\hline House rental & 1 month & 400.000 \\
\hline Electricity bill & 1 bulan & 150.000 \\
\hline Daily meal & $\begin{array}{c}\text { 3 times a day @ } \\
\text { IDR30.000 }\end{array}$ & 900.000 \\
\hline Cellular cost & 1 month & 100.000 \\
\hline Transportation & $\begin{array}{c}\text { 20 working days } \\
\text { @ IDR10,000 }\end{array}$ & 200.000 \\
\hline Kids' allowance & $\begin{array}{c}\text { 24-day school } \\
\text { children @ } \\
\text { IDR5,000 x 2 kids } \\
\text { Kitchen wares and }\end{array}$ & $\begin{array}{c}\text { Rice, Onion, } \\
\text { chili, detergent } \\
\text { and others }\end{array}$ \\
\hline \multicolumn{3}{c}{ TOTAL needs } \\
\hline
\end{tabular}

Table 8 Details of Household Expenditure after the Increase in Basic Tariff of Electricity price

\begin{tabular}{lcc}
\hline Item & Descriptions & $\begin{array}{l}\text { Amount } \\
\text { (IDR) }\end{array}$ \\
\hline House rental & 1 month & 400.000 \\
\hline Electricity bill & 1 bulan & 300.000 \\
\hline Daily meal & $\begin{array}{c}\text { 3 times a day @ } \\
\text { IDR30.000 }\end{array}$ & 900.000 \\
\hline Cellular cost & 1 month & 100.000 \\
\hline $\begin{array}{l}\text { Transportatio } \\
\mathrm{n}\end{array}$ & $\begin{array}{c}\text { 20 working days @ } \\
\text { IDR10,000 }\end{array}$ \\
\hline $\begin{array}{l}\text { Kids' } \\
\text { allowance }\end{array}$ & $\begin{array}{c}\text { 24-day school } \\
\text { children @ IDR 5,000 } \\
\text { x 2 kids }\end{array}$ \\
\hline $\begin{array}{l}\text { Kitchen } \\
\text { wares and } \\
\text { daily needs }\end{array}$ & $\begin{array}{c}\text { Rice, Onion, chili, } \\
\text { detergent and others }\end{array}$ \\
\hline TOTAL & 350.0000 \\
\hline
\end{tabular}

Table 8 with an average basic tariff (TDL) increase of IDR150,000 for electricity capacity of 900 VA, then the former household expenditure for electricity amounted to IDR150,000 to IDR300,000 after the increase in TDL. Income is still IDR2,300,000 while expenses increase to IDR2,490,000 after the increase of TDL. If by simple logic it is impossible to live with greater expenditure than income, but that is the smartness of those who are in simple life to respond to expenses. But the truth is not what it should be done because the welfare of the community that needs to be considered. Golgher (2016) in her research found that the household was set according to the needs and budget better for the rest of the consumption function for non-consumption expenditures including paying bills.

Ntsalaze (2017) stated that the household is vulnerable to debt when they could not meet their financial needs, therefore all non-essential spending will be minimized. According to Obben (2011) that increased household spending will automatically reduce your ability to save money. Dong (2012) 
mentioned that the household with too much credit will tend to have lower productivity than those who are not. Sulistiawati (2012) said that those who have low productivity are very susceptible to be exposed to any termination of employment relationships (LAYOFFS).

For electric capacities of 1200 VA and above 1200 VA which have also increased did not influence much $t$ because those who use it are people whose income or salary is above IDR2,300,000. Their electricity bill ranges from IDR600,000 to IDR1,000,000 Per month. Surely those who choose to use 1200 VA electricity are classified as affordable family, thus the increase does not matter the family expenses.

For those who use 900 VA power will certainly feel very heavy with the increase because of the economic conditions prior to the rise in tariff (TDL) has been burdensome, let alone with the rise in basic tariff (TDL), The increase of IDR150,000 has been a big burden for family with low incomes or according to minimum wage.

\section{Industrial Electricity tariff increase}

Ministry of industry calculates there are at least 400 companies that will be affected by the basic electric rate increase. Ms. Hidayat, Minister of industry concerned, the increase in electricity rates that hit hundreds of industries could inhibit the growth of the industrial sector.

According to Mulyati (2008), the electric base rate for the industry is influenced by three factors, namely the cost of capital, cost of operation and maintenance, and fuel costs. Higher electricity rates will make the burden of the cost of production of the more heavily. In addition, basic electricity rate increase could disrupt the company's cash flow. On the one hand, the company should improve the competitiveness of production capacity and quality of goods to welcome the ASEAN Economic Community next year.

This year, 2017, minister of industry is targeting the growth of oil and gas industry by $6.4 \%$ from a year ago. Some industries like basic metal industries of iron and steel, industrial tools, machinery and transport equipment, as well as the textile industry, leather goods and footwear are estimated to be a motor mover manufacturing industry. Among the industrial sectors, the industry using electricity is steel and textiles (kemenperin.go.id).

Bank of Indonesia (BI) estimates the price increase of electricity rates as a consequence of the rise of subsidies on electricity, 900volt ampere (VA) and $450 \mathrm{VA}$ and liquefied petroleum gas tariff increase, three kilogram $(\mathrm{kg})$ contributes up to $1 \%$. Perry Warjiyo, Governor Deputy of BI said, the total weight of administered prices against the national inflation is not too large, i.e. only reached $18 \%$. BI estimates, without taking into account the increase in the electricity tariff base and petroleum gas $(3 \mathrm{~kg})$ and other policies administered by government, the national inflation in 2017 could reach $3.6 \%$.

It is known that in addition to the major industry there is also a cottage industry of production activities at home. Surely, they also affected the electricity rate increase induced drag. The high cost of industrial production will affect the selling price of the industrial product and if this happens then the feel of its impact is the purchasing power of households of the community. In addition, industrial production ships also affected due to the increase in TDL (Nugroho, 2011). But the good news for the industry, household, using current and voltage sensor, can detect the consumption current and voltage on the load so that it can be directly read by the sensor. Thus, the optimization of the installed power usage can be achieved to the maximum load and can be operated for business process well (Handajadi, 2015).

\section{The Impact of Electricity Tariff Increase towards Households}

The revocation of nonsubsidized tariff will take place in three stages, first from 1 January 2017 to June 2017. "The increase in electricity tariff is indeed applied per period determined by the government based on economic prices". Dermorejo (2003) states that, an increase in electricity tariff 
could cause other sectors to increase especially in terms of basic needs. Patriadi (2005) states that the burden of non-fuel subsidies (including electricity subsidies) is relatively light compared to fuel subsidies, so it is not fundamental if the government reduces electricity subsidies for the community. The 450 watts power capacity have been extremely rare since most are already switched using a 900 watts capacity due to the rising needs of the household appliances such as a TV, a refrigerator, fan, rice cooker, Dispenser, Iron, air conditioning and washing machine. Therefore, the electricity tariff policy of 900 watts capacity was granted since it will cause inflation.

Krasniqi (2009) sets forth that home is an early phase to begin the process of entrepreneurships run by young generations. In case of basic electricity rate increase, it will affect the occurrence of increased operational costs. The average individual-run venture capital is sourced from personal funds (Hendrojogi, 2015).

Not all home-based businesses have a huge turnover but they are doing business just to survive. How can businesses keep running amid rising operational costs due to the increase in home-based businesses, whereas TDL (basic tariff) is the solution to reduce unemployment problems. Then in order to establish permanent nature of employment, self-employment program should, then, be created (Jingan, 2016).

Inflation becomes something frightening when the government raises electricity and fuel tariffs, sometimes the government conducts market operations to curb price fluctuations but do not let the government buy cheap rice to the public. Malian (2008) states that the policy of cheap rice prices is not recommended because it only harms rice farmers. According to Rochaeni (2005), the expenditure of peasant society for consumption of $50.29 \%$ it will be felt for the family of farmers or those who produce mediocre if you have to spend additional money for electricity needs, not to mention employees who have your minimum wage, weight with the addition of expenditure while income does not increase

Widayat (2017) states that, poverty itself is the inability of a person to meet the primarily needs such as food, clothing, shelter, education and health. There are some things that cause poverty: percapita income slump, declining productivity, cost of living increases, subsidies are not right on target, employment and urban population are not balance.

Interviews conducted noted that the families are not supposed to have a healthy four-fifth perfect meal, because they are already grateful to have daily food two or three times a day without any supplement. Not to mention if the household also opened a small business such as opening a juice shop that uses electricity for operational charge, raising the selling price is not possible because it will burden the consumer then the only way to give up profits are thinning.

For the long term, it is probable that if government revokes the subsidies of electricity, it could trigger poverty among the societies. It is necessary to evaluate the tariff increase because it is very burdensome for the lower economic community, if basic tariff of electricity price is raised, it should be better clustered based on the income or just let $900 \mathrm{VA}$ electric power remains as it was, no increase. The option of subsidizing $900 \mathrm{VA}$ of electricity is on average considering its usage ranges for lamps of 20 watts to 45 watts, cooking rice, fans or air conditioner and television. This is a standard requirement of the community, in contrast to those who use 1200 VA electricity and above vary according to the family's standard, like Lights greater than 60 watts, more than one TV, washing machine, more than one air conditioner, rice cooker, Refrigerator, pumping machine water and others.

\section{Conclusions}

It is advisable for the government consider and evaluate the policy in raising basic tariff because it is very heavy for the community to face and overcome the burden in difficult conditions in order to survive amid high living costs. Electricity is no longer a secondary need but it includes the primary 
needs in the community, the economic capacity of the community is still weak which is seen from $57 \%$ of them are still earning minimum wage.

\section{References}

Dermorejo, S. K. (2003). Analisis kebijakan hubungan antar sektor perekonomian nasional. Jurnal Analisis Kebijakan Pertanian, 1(4).

Dong, F., Jing L. \& Allen, M, F. (2012). Effect of credit constraints on household productivity in rural China. Agriculture Finance review, 73(3).

Golgher, Andre. (2016). Multidimensional poverty in urban Brazil: Income, assets and expenses. International Journal of Social Economics, 43(1).

Handajadi, W. (2015). Manajemen energi upaya peningkatan kualitas daya listrik dalam industri rumah tangga. The $2^{\text {nd }}$ University Research Coloquium. ISSN 2407-9189.

Hendrojogi. (2015). Koperasi : Asas-asas, Teori dan praktik. Edisi revisi. The 10 $0^{\text {th }}$ Edition. Jakarta: PT RajaGrafindo Persada.

Jingan., ML. (2016). Ekonomi Pembangunan dan Perencanaan. The $16^{\text {th }}$ Edition. Jakarta: PT Raja Grafindo Persada.

Krasniqi, B. A. (2009). Personal household and business environmental determinants of enterpreneurship. Journal of Small Business and Enterprise Development, 16(1).

Malian, A., et al. (2004). Faktor-faktor yang mempengaruhi produksi konsumsi dan harga beras serta inflasi bahan makanan. Jurnal Agro Ekonomi, 22(2).

Mulyati, M. (2008). Penetapan tarif dasar listrik (TDL) untuk sektor industri di Indonesia. Jurnal Teknik Industri, 8(1).

Ntsalaze, L., \& Sylvanus, I. (2018) The threshold effects of household indebtedness on multidimensional poverty. International Journal of Social Economics, 44 (11).

Nugroho, V, P., and Triwilaswandio W.P. (2012). Permodelan risiko kenaikan tarif dasar listrik terhadap biaya produksi kapal baru. Jurnal Teknik ITS, 1(1)

Obben, J., \& Monique, W. (2011) New Zealand's old-age pension scheme and household saving. International Journal of Social Economics, 38(9).

Patriadi, P., \& Rudi, H. (2005). Evaluasi kebijakan subsidi non BBM. Jurnal Kajian Ekonomi dan Keuangan, 9(4).

Purbaningrum, S, P. (2014). Audit energi dan analisis peluang penghematan konsumsi energi listrik pada rumah tangga. Media Mesin, 15(1).

Rochaeni, S and Erna M, L. (2005). Faktor-faktor yang mempengaruhi keputusan ekonomi rumah tangga petani di Kelurahan Setugede kota Bogor. Jurnal Agro Ekonomi, P-ISSN 0216-9053 EISSN 254-11527, 23(2).

Sulistiawati, R. (2013). Pengaruh upah minimum terhadap penyerapan tenaga kerja dan kesejahteraan masyarakat di Provinsi di Indonesia. Jurnal EKSOS, 8(3).

Widayat, P. (2017). Perekonomian Indonesia. CV Karya Nofa. Pekanbaru. 